\title{
Physiological responses and lactational performances of late-lactation dairy goats under heat stress conditions
}

\author{
S. Hamzaoui, ${ }^{*}$ A. A. K. Salama, ${ }^{*}{ }^{1}$ E. Albanell, ${ }^{*} X$. Such, ${ }^{*}$ and G. Caja* \\ ${ }^{*}$ Grup de Recerca en Remugants (G2R), Departament de Ciència Animal i dels Aliments, Universitat Autònoma de Barcelona, \\ 08193 Bellaterra, Spain \\ †Sheep and Goat Research Department, Animal Production Research Institute, 12311 Dokki, Giza, Egypt
}

\begin{abstract}
Eight Murciano-Granadina dairy goats in late lactation were exposed to different ambient conditions, using metabolic cages in a climatic chamber. The experimental design was a crossover (2 periods of $35 \mathrm{~d}$ and 4 goats each) and conditions were (1) thermal neutral (TN; 15 to $20^{\circ} \mathrm{C}$ day-night) and (2) heat stress (HS; 12 -h day at $37^{\circ} \mathrm{C}$ and 12 -h night at $30.5^{\circ} \mathrm{C}$ ). Humidity was maintained at $40 \%$ and light-dark was constant $(12-12 \mathrm{~h})$. The forage:concentrate ratio was adjusted daily for maintaining similar value in TN and HS goats (70:30). Water was freely available at ambient temperature. Rectal temperature and respiratory rate $(0800$, 1200 and $1700 \mathrm{~h}$ ) and milk yield were recorded daily, whereas milk composition, nonesterified fatty acids and haptoglobin in blood were analyzed weekly. At d 25 , additional blood samples were taken for analysis of metabolites and indicators of the acid-base balance. Digestibility coefficients and $\mathrm{N}$ balance were determined (d 31 to 35) and body weight was recorded (d 35). Compared with TN goats, HS goats experienced greater rectal temperature $\left(+0.58^{\circ} \mathrm{C}\right)$, respiratory rate $(+48$ breaths $/ \mathrm{min})$, water intake $(+77 \%)$ and water evaporation $(+207 \%)$. Intake of HS goats rapidly declined until d $7(-40 \%)$, partially recovered from d 7 to 19 , and steadied thereafter $(-14 \%)$. No changes in digestibility or $\mathrm{N}$ balance were detected. Blood nonesterified fatty acids and haptoglobin peaked at d 7 in HS goats but did not vary thereafter. Although milk yield did not vary by treatment, milk of HS goats contained $-12.5 \%$ protein and $-11.5 \%$ casein than TN goats. Panting reduced concentration and pressure of $\mathrm{CO}_{2}$ in the blood of HS goats, but they were able to maintain their blood $\mathrm{pH}$ similar to the TN group by lowering $\mathrm{HCO}_{3}{ }^{-}$and increasing $\mathrm{Cl}^{-}$concentrations in their blood. In conclusion, HS dairy goats showed dramatic physiological changes during the first week of treatment and partially recovered thereafter. They were able to maintain milk
\end{abstract}

Received February 4, 2013.

Accepted July 2, 2013.

${ }^{1}$ Corresponding author: ahmed.salama@uab.es yield by losing body mass, but milk protein content and protein yield were depressed. Further research is needed to assess the response of dairy goats to HS at earlier stages of lactation.

Key words: heat stress, lactation, digestibility, dairy goat

\section{INTRODUCTION}

Heat stress (HS) decreases milk production of dairy animals, and half of this reduction in milk yield is due to reduced DMI (Rhoads et al., 2009). The other half of milk yield losses could be explained by the increase in maintenance requirements (NRC, 2007), decreasing secretion of growth hormone (Mitra et al., 1972), lowering blood flow to the udder (Lough et al., 1990), downregulating milk protein genes, and upregulating apoptosis genes in the mammary gland (Collier et al., 2006). Cows under HS had greater levels of insulin with improved insulin sensitivity and lacked the ability of fat mobilization from adipose tissue to face the decreased DMI (Baumgard and Rhoads, 2013). The reduction in dairy farm profit associated with HS when the temperature-humidity index (THI) is extremely high is not only a result of decreased milk yield, but also includes impaired milk quality, reproduction problems, increased health care costs, and even animal death.

Despite the large number of studies carried out in dairy cows, little is known about the effects of HS in dairy goats. Goats are considered more tolerant to high THI values compared with dairy cows because of their metabolic size and high water-conservation capacity (Silanikove, 2000). When environmental temperatures increased from 20 to $40^{\circ} \mathrm{C}$, respiration rate increased from 30 to over 200 breaths/min in East African goats (Maloiy and Taylor, 1971) and domestic Swedish goats (Olsson et al., 1995), indicating that water evaporation by respiration plays an important role in heat dissipation in goats.

Lactating Saanen goats exposed to moderate or severe HS for $4 \mathrm{~d}$ (THI $=81$ or 89 ) lost milk yield by 3 or $13 \%$, respectively (Sano et al., 1985). Brown et al. (1988) reported that the exposure of dairy goats 
to moderate $\mathrm{HS}$ conditions for $5 \mathrm{wk}\left(34^{\circ} \mathrm{C}\right.$ and $25 \%$ humidity; THI $=79$ ) depressed milk yield in Alpine but not in Nubian goats, indicating that the response to HS varies according to breed.

The objective of the current study was to measure the physiological, lactational, and nutritional responses to extreme heat stress conditions in Spanish MurcianoGranadina dairy goats in late lactation. Moreover, blood acid-base status and stress indicators were also evaluated. No information is available on the effects of HS on this dairy breed, which is widely spread in the Mediterranean area.

\section{MATERIALS AND METHODS}

\section{Animal and Management Conditions}

Animal care conditions and management practices agreed with the procedures stated by the Ethical Committee of Animal and Human Experimentation of the Universitat Autònoma de Barcelona (Bellaterra, Spain; CEEAH reference 09/771) and the codes of recommendations for the welfare of livestock of the Ministry of Agriculture, Food and Environment of Spain (Madrid).

Eight open multiparous Murciano-Granadina dairy goats $(43.5 \pm 2.6 \mathrm{~kg}$ of BW) with healthy and symmetrical udders, from the herd of the experimental farm of the Universitat Autònoma de Barcelona were blocked in 2 balanced groups and used at late lactation $(194 \pm 3$ DIM; $1.53 \pm 0.04 \mathrm{~L} / \mathrm{d})$. The experimental design was a crossover with 2 treatments in 2 periods, lasting $35 \mathrm{~d}$, and 4 goats each. Goats were switched to the opposite treatment in the second period. Climatic conditions were (1) thermal neutral $\left(\mathbf{T N} ; 15\right.$ to $20^{\circ} \mathrm{C}$ and $45 \%$ relative humidity; THI $=59$ to 65 ) and (2) HS (12-h day at $37^{\circ} \mathrm{C}$ and $40 \%$ relative humidity; $\mathrm{THI}=$ 85 ; and 12 -h night at $30.5^{\circ} \mathrm{C}$ and $40 \%$ relative humidity; THI $=77$ ). The order of treatments on each goat was recorded and taken into account in the statistical analyses. The THI values were calculated according to NRC (1971) as follows:

$$
\begin{aligned}
\mathrm{THI}=(1.8 \times & \left.\mathrm{T}_{\mathrm{db}}+32\right)-[(0.55-0.0055 \times \mathrm{RH}) \\
& \left.\times\left(1.8 \times \mathrm{T}_{\mathrm{db}}-26.8\right)\right]
\end{aligned}
$$

where $\mathrm{T}_{\mathrm{db}}$ is the dry bulb temperature $\left({ }^{\circ} \mathrm{C}\right)$ and $\mathrm{RH}$ is the relative humidity (\%).

Throughout the experiment, (mid-January to midApril), the TN goats were kept indoors and the temperature was maintained at 15 to $20^{\circ} \mathrm{C}$ with the help of an electric heather equipped with a thermostat (3.5 kW; General Electric, Barcelona, Spain). The temperature and relative humidity averaged $16.7 \pm 0.3^{\circ} \mathrm{C}$ and
$45 \pm 5 \%(\mathrm{THI}=61)$ for the TN goats. The HS goats were kept in a $4 \times 6 \times 2.3-\mathrm{m}$ climatic chamber $(\mathrm{Eu}-$ roshield; ETS Lindgren-Euroshield Oy, Eura, Finland) provided with a temperature and humidity controlling system (Carel Controls Ibérica, S.L., Barcelona, Spain). A continuous $90 \mathrm{~m}^{3} / \mathrm{h}$ air turnover was maintained throughout the experiment.

Goats had a 4-wk preexperimental period under TN conditions for adaptation to the diet and to metabolic cages. When goats were switched from TN to HS conditions, a transition period of $2 \mathrm{~d}$ was allowed $(1 \mathrm{~d}$ at $25^{\circ} \mathrm{C}$ and $1 \mathrm{~d}$ at $30^{\circ} \mathrm{C}$ ), but no transition was applied for the change from HS to TN. Photoperiod was maintained constant at 12-h light:12-h dark (0900 to $2100 \mathrm{~h}$ ) and data of environmental temperature and humidity were recorded every $10 \mathrm{~min}$ by using 2 data loggers (Opus 10; Lufft Mess- und Regeltechnik GmbH, Fellbach, Germany).

Daily ration of the goats consisted of (as-fed) dehydrated fescue hay ad libitum (20\% daily refusal), 0.65 $\mathrm{kg}$ of alfalfa pellets, and $0.8 \mathrm{~kg}$ of concentrate mixture (30\% corn, $25.8 \%$ barley, $25 \%$ soybean meal, $8.5 \%$ sunflower meal, $5 \%$ FA sodium salts, $2.5 \%$ dicalcium phosphate, $2 \%$ calcium carbonate, $1 \%$ sodium chloride, and $0.2 \%$ vitamins $\mathrm{A}, \mathrm{E}$, and $\mathrm{D}_{3}$; as fed). Mineralized salt blocks were freely available in each metabolic cage (composition: $36.74 \% \mathrm{Na}, 0.32 \% \mathrm{Ca}, 1.09 \% \mathrm{Mg}$, $5 \mathrm{~g}$ of $\mathrm{Zn} / \mathrm{kg}, 1.5 \mathrm{~g}$ of $\mathrm{Mn} / \mathrm{kg} .912 \mathrm{mg}$ of $\mathrm{S} / \mathrm{kg}, 304$ $\mathrm{mg}$ of $\mathrm{Fe} / \mathrm{kg}, 75 \mathrm{mg}$ of $\mathrm{I} / \mathrm{kg}, 50 \mathrm{mg}$ of $\mathrm{Co} / \mathrm{kg}$, and 25 mg of Se/kg; Ovi Bloc; Sal Cupido, Terrassa, Spain). The concentrate mixture was offered in 2 daily portions at 0900 and $1600 \mathrm{~h}$. Changes in the forage intake of the HS goats were taken into account throughout the experiment and the amount of concentrate offered was daily modified to maintain a constant and similar forage:concentrate ratio to that of the TN goats. Clean water was permanently available at ambient temperature, according to treatment.

Goats were milked once daily $(0800 \mathrm{~h})$ with a portable milking machine (Westfalia Separator Ibérica SA, Granollers, Spain) set at $42 \mathrm{kPa}, 90$ pulses/min, and $66 \%$ pulsation ratio, provided with recording jars $(2$ $\mathrm{L} \pm 5 \%$ ). Milking routine included cluster attachment without udder preparation or teat cleaning, machine milking, machine stripping before cluster removal, and teat dipping in an iodine solution (P3-io shield; Ecolab Hispano-Portuguesa S. L., Barcelona, Spain).

\section{Sample Collection, Analyses, and Measurements}

Body Temperature and Respiration Rate. Rectal temperatures and respiration rates were recorded at 0800, 1200, and $1700 \mathrm{~h}$. Rectal temperature was mea- 
sured by a digital clinical thermometer (model "mini color"; ICO Technology, Barcelona, Spain; range, 32 to $43.9^{\circ} \mathrm{C}$; accuracy, $\pm 0.1^{\circ} \mathrm{C}$ ), whereas the number of inhalations and exhalations during $60 \mathrm{~s}$ indicated the respiration rate.

Feed Intake and Water Consumption. Feed intake and water consumption (accuracy: $\pm 20 \mathrm{~g}$ ) were recorded daily throughout the experiment. Trays with saw dust were put below the drinking troughs and weighted twice daily to take into account water wastes. Feed samples were collected before the beginning of each experimental period and were ground through a 1-mm stainless steel screen, and then analyzed for DM, $\mathrm{ADF}, \mathrm{NDF}$, and ash content according to analytical standard methods (AOAC International, 2003). The Dumas method (AOAC International, 2003) with a Leco analyzer (Leco Corp., St. Joseph, MI) was used for $\mathrm{N}$ determinations and $\mathrm{CP}$ was calculated as percentage of $\mathrm{N} \times 6.25$. The chemical composition and nutritive value of ration ingredients are shown in Table 1.

Milk Yield and Milk Composition. Milk yield of individual goats was recorded daily throughout the experiment and milk composition was evaluated weekly. A milk sample of approximately $100 \mathrm{~mL}$ was collected and preserved with an antimicrobial tablet (bronopol, Broad Spectrum Microtabs II; D \& F Control Systems Inc., San Ramon, CA) at $4^{\circ} \mathrm{C}$ until analysis. Milk samples were analyzed with a near-infrared spectrometer (Foss NIRSystems 5000; Foss Electric A/S, Hillerød, Denmark) for contents of TS, fat, total protein $(\mathrm{N} \times$ 6.38 ), true protein, and CN. Whey protein was calcu- lated by the difference between true protein and $\mathrm{CN}$, and NPN was calculated by the difference between total protein and true protein.

Blood Measures. Blood samples were taken weekly from the jugular vein into $10-\mathrm{mL}$ plastic lavender Vacutainers with spray-coated $\mathrm{K}_{2}$-EDTA (BD Diagnostics, Franklin Lakes, NJ) before the morning feeding. Plasma was obtained by centrifugation of whole blood for $15 \mathrm{~min}$ at $1,500 \times \mathrm{g}$ at $4^{\circ} \mathrm{C}$, and stored at $-20^{\circ} \mathrm{C}$ for the NEFA and haptoglobin analyses. The NEFA were determined by the colorimetric enzymatic test ACS-ACOD method using a commercial kit (Wako Chemicals GmbH, Neuss, Germany). Haptoglobin concentration was determined colorimetrically by the hemoglobin-binding method using a commercial haptoglobin assay (Assay phase Range; Tridelta Development Ltd., Maynooth, Ireland) and an Olympus AU400 analyzer (Olympus Europa Holding GmbH, Hamburg, Germany).

At d 25, blood samples (approximately $0.3 \mathrm{~mL}$ ) were collected using insulin syringes $(1 \mathrm{~mL}$; BD Micro-Fine; BD Medical-Diabetes Care, Franklin Lakes, NJ) at 0800 and at $1700 \mathrm{~h}$ and immediately analyzed for major ions and metabolites. A single drop of blood was applied to disposable cartridges containing biochemical and silicon chip technology (i-STAT EC8+; Abbott Point of Care Inc., Princeton, NJ). Then, the cartridge was inserted into an i-STAT hand-held analyzer, and the results of glucose, urea, $\mathrm{Cl}, \mathrm{Na}, \mathrm{K}$, total $\mathrm{CO}_{2}$ concentration, anion gap, hematocrit, hemoglobin, $\mathrm{pH}$, partial pressure of $\mathrm{CO}_{2}, \mathrm{HCO}_{3}^{-}$, and base excess were obtained.

Table 1. Chemical composition and nutritive value (DM basis) of the ration ingredients used for dairy goats

\begin{tabular}{|c|c|c|c|}
\hline Item & $\begin{array}{c}\text { Fescue } \\
\text { hay }\end{array}$ & $\begin{array}{l}\text { Alfalfa } \\
\text { pellets }\end{array}$ & Concentrate \\
\hline \multicolumn{4}{|l|}{ Component } \\
\hline DM, \% & 89.99 & 93.04 & 90.30 \\
\hline $\mathrm{OM}, \%$ of $\mathrm{DM}$ & 89.70 & 86.50 & 88.60 \\
\hline $\mathrm{CP}, \%$ of $\mathrm{DM}$ & 10.60 & 12.60 & 17.90 \\
\hline $\mathrm{NDF}, \%$ of DM & 48.10 & 44.90 & 12.60 \\
\hline $\mathrm{ADF}, \%$ of $\mathrm{DM}$ & 23.30 & 27.00 & 6.19 \\
\hline \multicolumn{4}{|l|}{ Nutritive value ${ }^{1}$} \\
\hline $\mathrm{UEm},{ }^{2} / \mathrm{kg}$ & 1.57 & - & - \\
\hline $\mathrm{UFL}^{3}, / \mathrm{kg}$ & 0.57 & 0.68 & 1.17 \\
\hline $\mathrm{NE}_{\mathrm{L}}, \mathrm{Mcal} / \mathrm{kg}$ & 0.97 & 1.16 & 1.99 \\
\hline PDIE,${ }^{4} \mathrm{~g} / \mathrm{kg}$ & 66 & 83 & 129 \\
\hline PDIN, ${ }^{5} \mathrm{~g} / \mathrm{kg}$ & 57 & 95 & 153 \\
\hline $\mathrm{PDIA}^{6}{ }^{6} \mathrm{~g} / \mathrm{kg}$ & 24 & 47 & 79 \\
\hline $\mathrm{Ca}, \mathrm{g} / \mathrm{kg}$ & 3.5 & 16.5 & 18.8 \\
\hline $\mathrm{P}, \mathrm{g} / \mathrm{kg}$ & 2.5 & 2.5 & 9.1 \\
\hline
\end{tabular}

${ }^{1}$ Calculated according to Institut National de la Recherche Agronomique (INRA, 2007).

${ }^{2}$ Fill units for sheep $(1 \mathrm{UEm}=1 \mathrm{~kg}$ of reference grass DM).

${ }^{3}$ Feed units for lactation $\left(1 \mathrm{UFL}=1.7 \mathrm{Mcal}\right.$ of $\left.\mathrm{NE}_{\mathrm{L}}\right)$.

${ }^{4}$ Protein digested in the small intestine supplied by microbial protein from rumen-fermented OM.

${ }^{5}$ Protein digested in the small intestine supplied by microbial protein from RDP.

${ }^{6}$ Protein digested in the small intestine supplied by RUP. 
Digestibility Coefficients, and Water and $N$ Balances. Feed orts were daily collected (d 31 to 35), weighed, and composted for analysis. Feces of each goat were daily collected and $10 \%$ of fresh feces were dried at $60^{\circ} \mathrm{C}$ for $48 \mathrm{~h}$. Then, a composted sample for each goat was stored at room temperature until analysis. Urine was collected in containers with $20 \mathrm{~mL}$ of $\mathrm{H}_{2} \mathrm{SO}_{4}$ (96\%) and urine volume was daily measured (accuracy: $\pm 2 \mathrm{~mL}$ ). Urine samples (5\% of total volume) were composted and stored at $-25^{\circ} \mathrm{C}$ for $\mathrm{N}$ content analysis. Samples of urine without $\mathrm{H}_{2} \mathrm{SO}_{4}$ were collected at 0800 and at $1700 \mathrm{~h}$ during the last 2 experimental days to measure urine $\mathrm{pH}$. Orts and feces samples were ground through a 1-mm stainless steel screen and then analyzed for DM, CP, CF, ADF, NDF, and ash content, as previously indicated. Water balance was also done during the digestibility period.

Corticosterone in Feces. Samples of fresh feces were collected on the last day of each experimental period and stored at $-25^{\circ} \mathrm{C}$ for corticosterone analysis. Fecal samples were first lyophilized, then extracted with methanol, and finally diluted 1:10 with the assay buffer of the kit. Analyses were performed in the Clinical Biochemistry Service of the Veterinary Faculty of the Universitat Autònoma de Barcelona using the commercially available ${ }^{125} \mathrm{I}$ RIA kit (rats and mice corticosterone kit; ICN Pharmaceuticals, Orangeburg, NY), as described by Morrow et al. (2002). Recovery of known amounts of corticosterone added to the processed samples was $59.8 \%$. The relationship between theoretical and true values of corticosterone in goat feces was linear $\left(\mathrm{y}=0.9919 \mathrm{x}-2.863 ; \mathrm{R}^{2}=0.997\right)$. The inter- and intra-assay coefficients of variation were 16.8 and $9.5 \%$, respectively.

\section{Statistical Analyses}

Data were analyzed by the PROC MIXED for repeated measurements of SAS version 9.1.3 (SAS Institute Inc., Cary, NC). The statistical mixed model contained the fixed effects of the treatment (HS vs. TN), day, and period; the random effect of the animal; the interactions treatment $\times$ day and treatment $\times$ period; and the residual error. The model took into account the possible carryover effects of previous HS periods through the treatment $\times$ period interaction. Data of performances (i.e., intake, water, and milk yield) and physiological indicators (i.e., rectal temperature and respiratory rate) were analyzed on a daily basis.

For blood parameters measured at 0800 and 1700 $\mathrm{h}$, the model included the effects of treatment, sampling hour, and period, and the interaction treatment $\times$ period and treatment $x$ hour. Data on digestibility and nutrient balance were analyzed using PROC GLM of SAS. The model contained the effect of treatment and period, the interaction treatment $\times$ period, and the residual error.

Data were tested for the normality of distribution, and a logarithmic transformation $\left(\log _{10}\right)$ was applied to haptoglobin concentration in blood. Differences between least squares means were determined with the PDIFF test of SAS. Significance was declared at $P<$ 0.05 unless otherwise indicated.

\section{RESULTS AND DISCUSSION}

\section{Rectal Temperature and Respiration Rate}

Rectal temperatures and respiration rates increased from 0800 to $1700 \mathrm{~h}$ in both goat groups, but were greater in HS than in TN goats at all time points (Figure $1 \mathrm{~A}$ and $1 \mathrm{~B} ; P<0.001)$. The increased rectal temperatures and respiration rates in TN goats from 0800 to $1700 \mathrm{~h}$ were in accordance with the increment in ambient temperature throughout the day $\left(15\right.$ to $\left.20^{\circ} \mathrm{C}\right)$. Comparing the HS goats at $0800 \mathrm{~h}$ (after being exposed to $30.5^{\circ} \mathrm{C}$ during the night; $\left.\mathrm{THI}=77\right)$ with $\mathrm{TN}$ goats at $1700 \mathrm{~h}(\mathrm{THI}=65)$, we observed similar rectal temperatures $\left(+0.04^{\circ} \mathrm{C} ; P=0.390\right)$ but greater respiration rates $(+13$ breaths $/ \mathrm{min} ; P<0.01)$, indicating that HS goats were under HS throughout the day, but to a lower extent during the night. Reference respiratory rate for adult goats ranges between 15 and 30 breaths/min according to Pugh and Baird (2012), but it was greater in our TN goats at $1700 \mathrm{~h}$, probably because of breed and physiological state differences. Maximum rectal temperature difference $\left(+0.70^{\circ} \mathrm{C} ; P<0.001\right)$ between HS and TN goats occurred at $1200 \mathrm{~h}$, whereas the largest difference in respiration rate $(+65$ breaths/min; $P$ $<0.001$ ) occurred at $1700 \mathrm{~h}$. Increased respiration rate under HS conditions is a known mechanism for dissipating heat load by evaporation. Rectal temperature and respiration rate values peaked in HS goats during the first week and then gradually decreased, which indicates a partial adaptation to the HS conditions.

\section{Feed Intake}

On average, DMI decreased by $21 \%$ throughout the 35-d experimental period but showed a marked effect of time elapsed after the start of the HS treatment (Figure 2; $P<0.001$ ). Feed intake under HS conditions gradually decreased during wk 1 , partially recovered during wk 2 and 3, and remained constant thereafter (Figure 2). Heat stress caused a $27 \%$ reduction in DMI from d 1 to $19(1.47 \pm 0.05$ vs. $2.00 \pm 0.06 \mathrm{~kg} / \mathrm{d} ; P<$ $0.001)$ and $14 \%$ from d 20 to 35 (1.75 \pm 0.06 vs. 2.03 

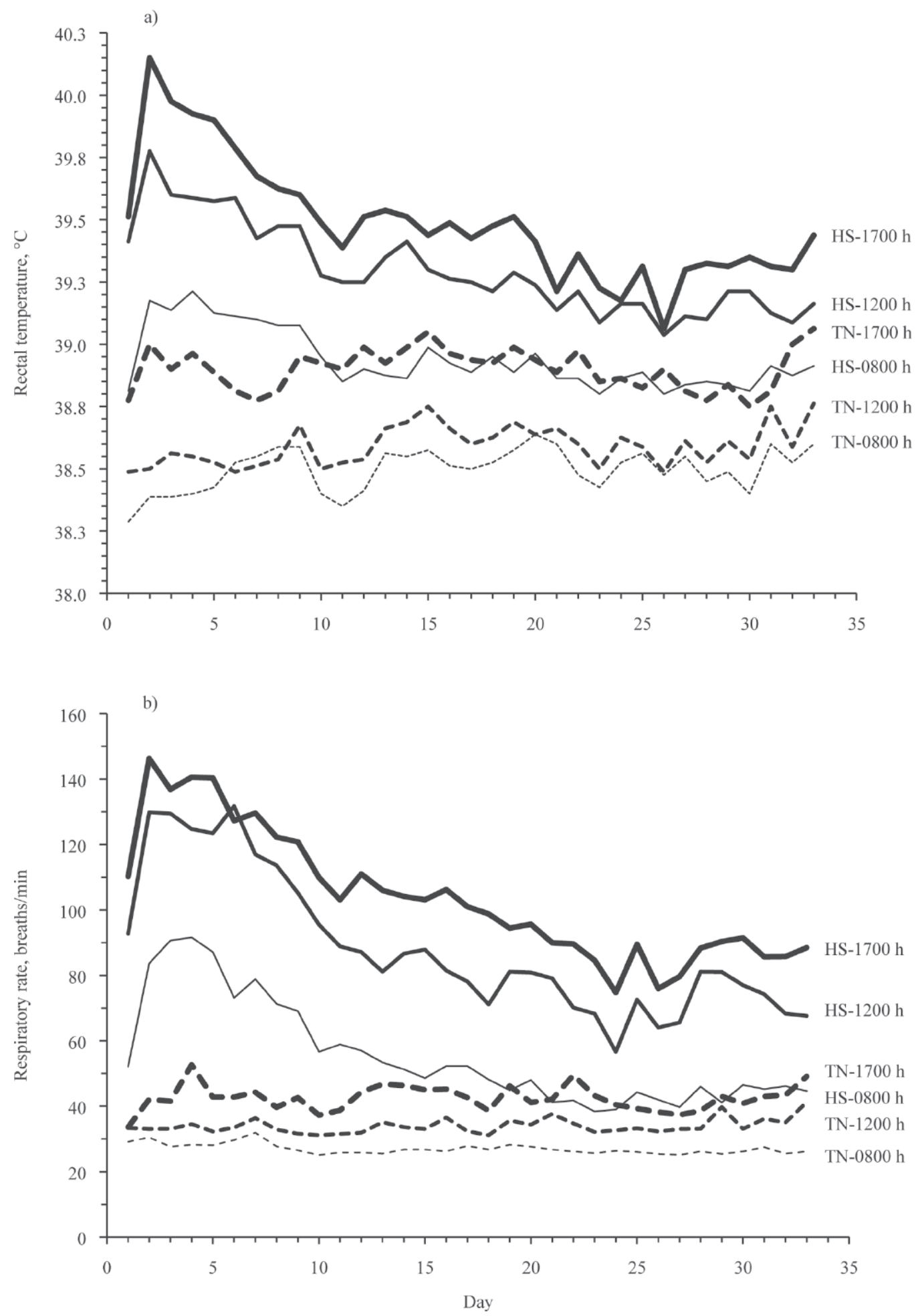

Figure 1. Rectal temperature (a) and respiratory rate (b) at different hours during the day (0800, 1200, and 1700 h) in dairy goats under thermal neutral (TN; dashed lines; $\mathrm{n}=8$ ) or heat stress (HS; solid lines; $\mathrm{n}=8$ ) conditions at late lactation.

$\pm 0.06 \mathrm{~kg} / \mathrm{d} ; P<0.001)$. The partial recovery of DMI from d 19 onwards indicates the adaptation of goats to HS conditions. Previous studies comparing TN and
HS chamber conditions under controlled conditions in dairy cows (Rhoads et al., 2009; Shwartz et al., 2009) did not show such an adaptation. 


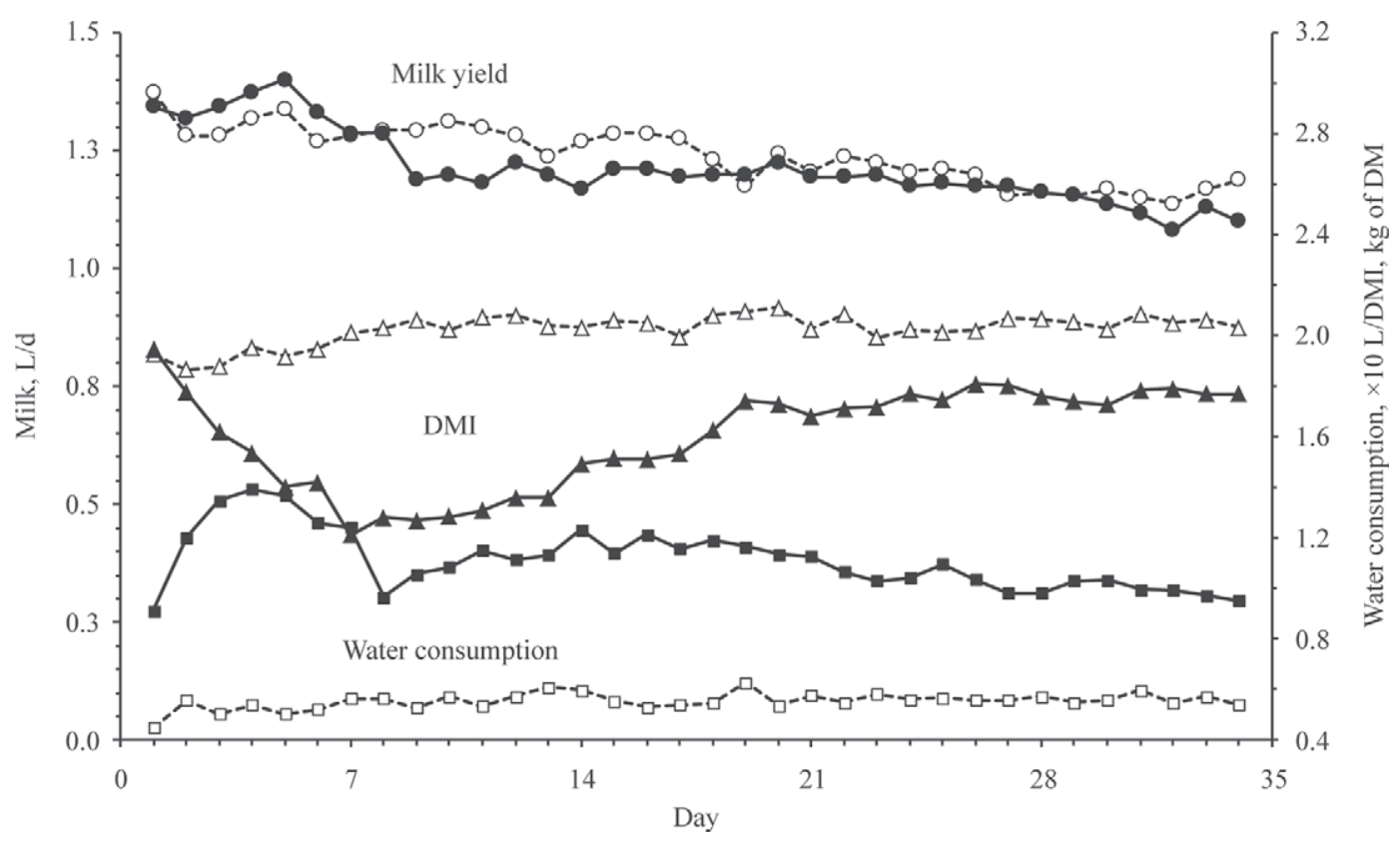

Figure 2. Milk yield ( $\bigcirc$ and $\bullet$ ), DMI ( $\Delta$ and $\mathbf{\Delta}$ ), and water consumption ( $\square$ and $\boldsymbol{\square}$ ) of dairy goats under thermal neutral $(\bigcirc, \Delta$, and $\square$ with dashed lines; $\mathrm{n}=8)$ or heat stress $(\boldsymbol{\bullet}, \boldsymbol{\Delta}$, and with solid lines; $\mathrm{n}=8)$ conditions at late lactation. The SEM values of milk yield, DMI, and water consumption are $0.05 \mathrm{~L}, 0.06 \mathrm{~kg}$, and $1.14 \mathrm{~L}$, respectively.

Feed intake reduction due to HS has been previously reported in dairy goats (Sano et al., 1985), ewes (Abdalla et al., 1993), and cows (Lough et al., 1990; Rhoads et al., 2009). Heat-stressed animals decreased feed intake in an attempt to create less metabolic heat because the heat increment of feeding, especially in ruminants, is an important source of heat production (Kadzere et al., 2002). Moreover, the gut fill by water observed in the current study for HS goats (see later) might also be related to the reduced DMI.

According to the lactational performances of our goats (Table 2) and the requirements estimated according to Institut National de la Recherche Agronomique (INRA, 2007), TN goats showed a greater feed intake $(2.03 \mathrm{~kg}$ of $\mathrm{DM} / \mathrm{d}$ or $4.6 \%$ of BW) than predicted $(1.72$ $\mathrm{kg}$ of $\mathrm{DM} / \mathrm{d}$ or $3.9 \%$ of $\mathrm{BW}$ ), which allowed them to cover their daily requirements $[1.16 \mathrm{UFL}$, where UFL $=$ feed units for lactation $(1 \mathrm{UFL}=1.7 \mathrm{Mcal}$ of NEL) and $102 \mathrm{~g}$ of PDI, where PDI = protein digested in the small intestine] and to have positive energy and protein balances $\left(+0.29 \mathrm{Mcal}\right.$ of $\mathrm{NE}_{\mathrm{L}}$ and $+80 \mathrm{~g}$ of PDI). Moreover, TN goats gained $1.8 \mathrm{~kg}(+51 \mathrm{~g} / \mathrm{d})$ during the experiment, as can be calculated from data shown in Table 2. On the other hand, feed intake of HS goats was lower $(1.60 \mathrm{~kg}$ of $\mathrm{DM} / \mathrm{d}$ or $3.7 \%$ of $\mathrm{BW})$ than predicted $(1.72 \mathrm{~kg}$ of $\mathrm{DM} / \mathrm{d}$ or $3.9 \%$ of $\mathrm{BW})$. If we also take into account a $30 \%$ increase in maintenance requirements because of HS, as indicated by NRC (2007), the energy intake would not be enough to cover the daily requirements and resulted in an apparent BW loss of $1.5 \mathrm{~kg}$ $(-41 \mathrm{~g} / \mathrm{d})$. The apparent BW changes in TN and HS goats included the inevitable variations in the digestive tract content, which were unknown in our data.

\section{Water Consumption and Water Balance}

Results of water consumption throughout the experiment and water balance measured from d 30 to 35 are shown in Tables 2 and 3, respectively. The HS goats had greater water consumption compared with TN goats $(+5.50 \mathrm{~L} / \mathrm{d} ; P<0.001)$. The greatest values of water intake were recorded during wk 1 when DMI was at its lowest value. However, water intake values stabilized earlier than DMI in the HS goats (Figure 2) and remained greater $(P<0.01)$ than in TN goats throughout the experiment. Increased water intake was mainly used by HS goats for boosting heat loss by evaporation from the skin (sweating) and by respiration (panting).

The total water evaporation calculated by subtracting water losses in milk, urine, and feces from water input (water intake + water in food) was 3 times greater (Table 3$)$ in HS goats than TN goats $(+2.23 \mathrm{~L} / \mathrm{d} ; P<$ $0.01)$. We were unable to distinguish between evaporation by sweating and panting, but increased sweating rates have been reported in heat-stressed dairy cows (Shwartz et al., 2009) and goats (Baker, 1989). 
Table 2. Lactational performance of Murciano-Granadina dairy goats under thermal neutral (TN; $\mathrm{n}=8)$ and heat stress (HS; $\mathrm{n}=8)$ conditions in late lactation [values are LSM and SE of the difference (SED)]

\begin{tabular}{|c|c|c|c|c|c|c|}
\hline \multirow[b]{2}{*}{ Item } & \multicolumn{2}{|c|}{ Treatment } & \multirow[b]{2}{*}{ SED } & \multicolumn{3}{|c|}{ Effect ( $P$-value $)$} \\
\hline & $\mathrm{TN}$ & HS & & Treatment & Period & $\mathrm{T} \times \mathrm{P}^{1}$ \\
\hline DMI, kg/d & 2.03 & 1.60 & 0.08 & 0.001 & 0.010 & 0.15 \\
\hline Water consumption, $\mathrm{L} / \mathrm{d}$ & 5.5 & 11.1 & 1.20 & 0.001 & 0.32 & 0.47 \\
\hline Milk yield, L/d & 1.24 & 1.21 & 0.02 & 0.20 & 0.001 & 0.67 \\
\hline TS & 12.89 & 12.41 & 0.29 & 0.26 & 0.62 & 0.73 \\
\hline Fat & 4.21 & 4.22 & 0.19 & 0.96 & 0.90 & 0.12 \\
\hline Protein & 3.84 & 3.36 & 0.15 & 0.030 & 0.79 & 0.99 \\
\hline True protein & 3.62 & 3.12 & 0.14 & 0.022 & 0.98 & 0.96 \\
\hline Casein & 3.21 & 2.84 & 0.12 & 0.034 & 0.18 & 0.71 \\
\hline Casein, $\%$ of protein & 84.1 & 84.9 & 0.64 & 0.20 & 0.001 & 0.091 \\
\hline Whey protein & 0.63 & 0.53 & 0.04 & 0.029 & 0.001 & 0.33 \\
\hline
\end{tabular}

${ }^{1}$ Interaction of treatment $(\mathrm{T}) \times \operatorname{period}(\mathrm{P})$.

${ }^{2} 3.5 \% \mathrm{FCM}=\mathrm{L}$ of milk yield $\times[0.432+0.162 \times($ fat $\%)]$.

${ }^{3}$ Average values of blood samples collected weekly from d 0 to d 35 .

\section{Milk Yield}

Despite the reduced DMI, increased body temperature, and the known negative effect of HS on milk production in dairy cows (West, 2003), milk yield and FCM did not vary between HS and TN goats (Table 2 and Figure 2; $P>0.05$ ). Brown et al. (1988) reported that the exposure of dairy goats to constant conditions of $34^{\circ} \mathrm{C}$ and $25 \%$ relative humidity ( $\mathrm{THI}=79$ ) for $5 \mathrm{wk}$ depressed milk yield in Alpine but not in Nubian goats.

Even when DMI was at its lowest value during the first week, milk yield was not affected in HS goats. During wk 1, HS goats may have been able to partially cover their lactation requirements by body fat mobilization, as indicated by the greater values of NEFA in plasma at d 7 of HS (Figure 3). From d 14 to 28 blood
NEFA levels were similar between groups, but our latelactation HS goats were probably able to maintain milk yield because they partially recovered DMI, tended to have greater digestibility (see later), and had lower metabolic demands compared with early-lactation goats. Milk yield response of dairy goats to HS in early lactation needs further research.

Our results of NEFA concentrations from d 14 to 28 (but not at d 7) agreed with findings obtained in dairy cows, where HS did not cause an increase in blood NEFA despite the reduced feed intake (Rhoads et al., 2009; Baumgard and Rhoads, 2013). Thus, it seems HS cows are more sensitive to insulin than TN cows, allowing a potent antilipolytic action of insulin that will prevent body fat mobilization. Consequently, lactating HS cows fail to have sufficient glucose for milk synthesis

Table 3. Water input and water losses of dairy goats under thermal neutral (TN; $n=8)$ and heat stress $($ HS; $n=8)$ conditions in late lactation [values are LSM and SE of the difference (SED)]

\begin{tabular}{|c|c|c|c|c|c|c|}
\hline Item & \multicolumn{2}{|c|}{ Treatment } & SED & \multicolumn{3}{|c|}{ Effect $(P$-value $)$} \\
\hline Water intake, ${ }^{2} \mathrm{~mL}$ & 5,504 & 9,728 & 1,863 & 0.035 & 0.86 & 0.64 \\
\hline Water in milk, ${ }^{2} \mathrm{~mL}$ & 969 & 1,004 & 62 & 0.55 & 0.16 & 0.29 \\
\hline Urine volume, ${ }^{2} \mathrm{~mL}$ & 2,143 & 4,757 & 1,737 & 0.41 & 0.99 & 0.80 \\
\hline Water in feces, $\mathrm{mL}$ & 1,426 & 825 & 144 & 0.002 & 0.33 & 0.18 \\
\hline
\end{tabular}

${ }^{1}$ Interaction of treatment $(\mathrm{T}) \times$ period $(\mathrm{P})$.

${ }^{2} P$-values were extracted after logarithmic transformation because of the nonnormal distribution of data.

${ }^{3}$ Calculated by the difference between water input (water intake + water in food) and water losses in milk, urine, and feces, without taking into account the water produced metabolically. 
6362

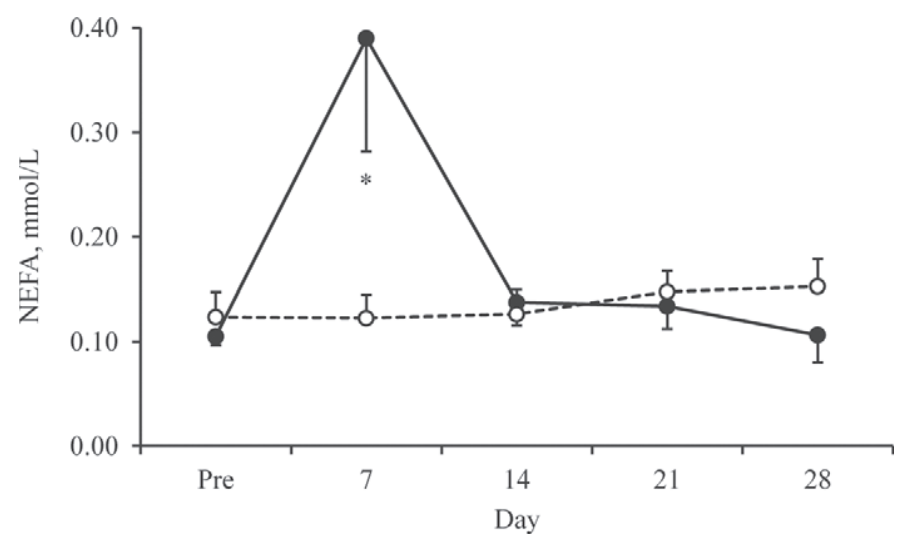

Figure 3. Plasma NEFA concentrations of dairy goats under thermal neutral ( $\mathrm{TN} ; \mathrm{O} ; \mathrm{n}=8$ ) or heat stress (HS; $\bullet \mathrm{n}=8$ ) conditions at late lactation. Values are means, with SE indicated by vertical bars. * indicates a difference at $P<0.001$ between TN and HS treatments.

and, therefore, milk yield was depressed. We did not observe such a decrease in milk yield in our HS goats, probably because the glucose was sufficient for the milk yield level at late lactation (see later).

\section{Milk Composition}

Milk TS and fat contents did not vary $(P>0.05)$ between HS and TN goats (Table 2). In short-term studies carried out using climate-controlled HS, milk fat was also not affected in cows (Rhoads et al., 2009; Shwartz et al., 2009) despite the known negative effect of summer on milk fat (Kadzere et al., 2002). This usual decrease in milk fat content of heat-stressed dairy cows during summer might be related to a reduction in forage intake, which could decrease the forage-to-concentrate ratio in the diet. In the current study, concentrate amount was adjusted according to the forage intake in HS goats to maintain a constant forage-to-concentrate ratio throughout the experiment and similar to that of TN goats.

With the exception of milk NPN, the content of protein and protein fractions in milk (true protein, $\mathrm{CN}$, and whey protein) were reduced by HS (Table 2). Nevertheless, the CN-to-protein ratio was not affected. Similarly, dairy cows under controlled conditions of HS decreased their milk protein content (Rhoads et al., 2009; Shwartz et al., 2009). Decreased protein intake and increased sweat secretion that contains protein and urea (Joshi et al., 1968) might have limited the availability of AA for milk protein synthesis. Moreover, the decrease in milk protein content under HS may be due to a lowered microbial protein synthesis in the rumen because of changes in rumen environment (dilution or clearance of soluble substances) by the high water intake. Huber et al. (1994) indicated that under decreased feed intake conditions, increasing the percentage of RUP and supplementing with lysine increased milk protein content under hot conditions in dairy cows. On the other hand, Bernabucci et al. (2002) suggested that decreased mammary synthesis of milk protein (rather than the reduction in AA intake) is the reason for the low milk protein during the hot season in dairy cows.

\section{Digestibility and Nitrogen Balance}

Goats under HS showed numerically greater values of digestibility and tended to have greater ADF digestibility than under TN conditions ( +3.1 points; $P<$ $0.10)$, as shown in Table 4. To our knowledge, no data are available comparing digestibility under $\mathrm{TN}$ and HS ambient conditions in lactating dairy goats. Our results agree with those of previous research carried out under climatic chamber conditions with male goats (Hirayama et al., 2004), dairy cows (McDowell et al., 1969) and heifers (Bernabucci et al., 1999). The increased digestibility in the HS treatments in the aforementioned studies might be partially due to the reduction of DMI as also observed for HS goats in our results (Table 2). Another reason for the enhanced digestibility under HS conditions could be a depressed passage rate of the solid phase of digesta as reported by Bernabucci et al. (1999). On the other hand, a greater rate of passage of the liquid phase of the digesta may be expected as a consequence of the dramatic increase in water intake. This could have an effect on the availability of rumen soluble fermentable compounds, although this statement needs experimental confirmation. The tendencies observed for an increased digestibility of nutrients (i.e., DM, OM, and ADF; Table 4) in the HS goats might have compensated the reduction in DMI, and could partially explain the lack of effects of HS on milk yield in our results.

Although HS goats had lower $\mathrm{N}$ intake (Table 4), as a consequence of the DMI reduction, they experienced lower $\mathrm{N}$ losses in feces and urine, which resulted in similar daily $\mathrm{N}$ retention in $\mathrm{TN}$ goats $(13.9 \pm 1.0 \mathrm{~g} / \mathrm{d}$, on average). Despite the similar $\mathrm{N}$ retention, milk protein content was lower in HS than in TN goats, indicating that ingested $\mathrm{N}$ would have been directed to other metabolic functions rather than milk protein synthesis in HS goats. It is possible that a portion of $\mathrm{N}$ intake was lost in sweat in the form of urea, as previously proposed by Joshi et al. (1968). Moreover, the possibility of a lower supply of essential AA for milk protein synthesis could not be excluded.

Treatment $\times$ period interactions were detected for DM and CP digestibilities, and for fecal excretion and apparent absorption of N (Table 4). These significant interactions could indicate some carryover effect when 
Table 4. Digestibility coefficients and nitrogen balance of dairy goats under thermal neutral $(\mathrm{TN} ; \mathrm{n}=8)$ and heat stress $($ HS; $\mathrm{n}=8)$ conditions in late lactation [values are LSM and SE of the difference (SED)]

\begin{tabular}{|c|c|c|c|c|c|c|}
\hline \multirow[b]{2}{*}{ Item } & \multicolumn{2}{|c|}{ Treatment } & \multirow[b]{2}{*}{ SED } & \multicolumn{3}{|c|}{ Effect $(P$-value $)$} \\
\hline & $\mathrm{TN}$ & HS & & Treatment & Period & $\mathrm{T} \times \mathrm{P}^{1}$ \\
\hline DM, \% & 56.6 & 58.8 & 2.3 & 0.12 & 0.57 & 0.047 \\
\hline $\mathrm{OM}, \%$ of $\mathrm{DM}$ & 58.8 & 61.2 & 1.4 & 0.11 & 0.41 & 0.058 \\
\hline $\mathrm{CP}, \%$ of $\mathrm{DM}$ & 70.5 & 72.1 & 1.5 & 0.31 & 0.72 & 0.021 \\
\hline NDF, \% of DM & 36.0 & 38.8 & 1.9 & 0.16 & 0.98 & 0.76 \\
\hline Intake, $\mathrm{g} / \mathrm{d}$ & 48.4 & 42.1 & 0.8 & 0.001 & 0.012 & 0.059 \\
\hline Fecal excretion, g/d & 14.3 & 11.8 & 0.8 & 0.010 & 0.35 & 0.017 \\
\hline Urinary excretion, $\mathrm{g} / \mathrm{d}$ & 20.3 & 16.4 & 1.3 & 0.012 & 0.96 & 0.27 \\
\hline Apparent absorption, \% & 70.5 & 72.1 & 1.5 & 0.31 & 0.72 & 0.021 \\
\hline Retention, g/d & 13.9 & 13.9 & 1.0 & 0.95 & 0.16 & 0.057 \\
\hline
\end{tabular}

${ }^{1}$ Interaction of treatment $(\mathrm{T}) \times$ period $(\mathrm{P})$.

HS goats went to the TN treatment in the second period. However, this seems unlikely in our case, as these interactions might result from the effect of period on DMI $(P<0.01$; Table 2$)$, where the DMI reduction in HS goats was more pronounced during period 2 compared with period 1 (data not shown).

\section{Blood Indicators and Urinary $\mathrm{pH}$}

Heat stress had no effect on blood glucose, urea, hematocrit, and hemoglobin concentrations (Table 5; $P>$ $0.05)$. A tendency in the treatment $\times$ hour interaction was detected for blood glucose $(P<0.10)$. At $0800 \mathrm{~h}$, HS goats showed lower glucose concentration than TN goats $(P<0.05)$, whereas the concentration at 1700 $\mathrm{h}$ increased $(P<0.001)$ and was similar to that of TN goats. It must be stressed that the morning blood samples were taken $1 \mathrm{~h}$ before offering the diet, whereas the afternoon sampling was done $1 \mathrm{~h}$ after distribution of the second portion of concentrate, which may have contributed to the similar blood glucose levels between groups at $1700 \mathrm{~h}$.

Blood $\mathrm{pH}$ is regulated by a complex system of buffers that continuously work to maintain it slightly basic in a range of 7.35 to 7.45 in most mammals (Constable, 1999). Measured blood $\mathrm{pH}$ was similar at 0800 in TN and HS goats, but slightly decreased at $1700 \mathrm{~h}(P<$ $0.05)$ in the TN goats. Despite the importance of blood $\mathrm{pH}$ for understanding the mechanism of respiratory evaporative heat loss, changes observed in our goats were marginally relevant and varied within the normal range in both TN and HS groups.

Values of total $\mathrm{CO}_{2}$, partial pressure of $\mathrm{CO}_{2}\left(\mathbf{p} \mathbf{C O}_{2}\right)$, $\mathrm{HCO}_{3}{ }^{-}$, and base excess were lower in HS compared with TN goats (Table 5; $P<0.01$ ). The deceased $\mathrm{pCO}_{2}$ and $\mathrm{HCO}_{3}{ }^{-}$under $\mathrm{HS}$ conditions agree with the results reported in dairy cows by Schneider et al. (1988). The greater respiration rate observed in panting HS goats contributed to a greater loss of $\mathrm{CO}_{2}$, lowering the carbonic acid content of the blood. As a consequence, $\mathrm{HCO}_{3}{ }^{-}$was transferred from the blood to urine by the kidney to maintain a constant blood $\mathrm{pH}$. Heat stress had no effect on blood $\mathrm{Na}$ and $\mathrm{K}$ concentrations in accordance with results previously reported in HS dairy cows (Schneider et al., 1988). On the other hand, Cl concentration was greater at both time points in HS than in TN goats (Table 5; $P<0.05$ ). Calamari et al. (2007) reported an inverse relationship between blood $\mathrm{HCO}_{3}{ }^{-}$and $\mathrm{Cl}$ in dairy cows under TN and HS conditions. Due to the greater $\mathrm{Cl}$ concentrations of the HS goats, they also have greater anion gap values, compared with TN goats (Table $5 ; P<0.05$ ). It was expected that the increased $\mathrm{HCO}_{3}{ }^{-}$secretion in the urine of $\mathrm{HS}$ goats should increase the urine $\mathrm{pH}$, but we observed the opposite, as the urine $\mathrm{pH}$ of HS goats tended $(P=0.11)$ to be lower than that of TN goats. We speculated that HS goats were able to increase their renal excretion of $\mathrm{H}^{+}$, which resulted in a partial reabsorption of $\mathrm{HCO}_{3}{ }^{-}$ into the blood, as previously observed by Masero and Siegel (1977). In fact, the decrease in $\mathrm{pCO}_{2}$ at $1700 \mathrm{~h}$ due to HS was more marked $(-20 \%)$ than the decrease in $\mathrm{HCO}_{3}{ }^{-}(-12 \%)$. The secretion of $\mathrm{HCO}_{3}{ }^{-}$in urine and its reabsorption suggests a large requirement and turnover of body bicarbonate to maintain blood $\mathrm{pH}$ during heat stress.

\section{Haptoglobin Concentration in Blood}

Haptoglobin (an acute-phase protein linked to metabolic stress) concentration in blood plasma was greater in HS than TN goats at d $7(P<0.05)$, when effects of HS were more marked, but differences between treatment groups disappeared at d 28 (Figure 4; $P>0.05$ ). Ametaj et al. (2005) indicated an association between 
Table 5. Metabolic and acid-base balance indicators of dairy goats under thermal neutral $(\mathrm{TN} ; \mathrm{n}=8)$ and heat stress $($ HS; $\mathrm{n}=8)$ conditions at different daily hours in late lactation (values are least squares means and SEM)

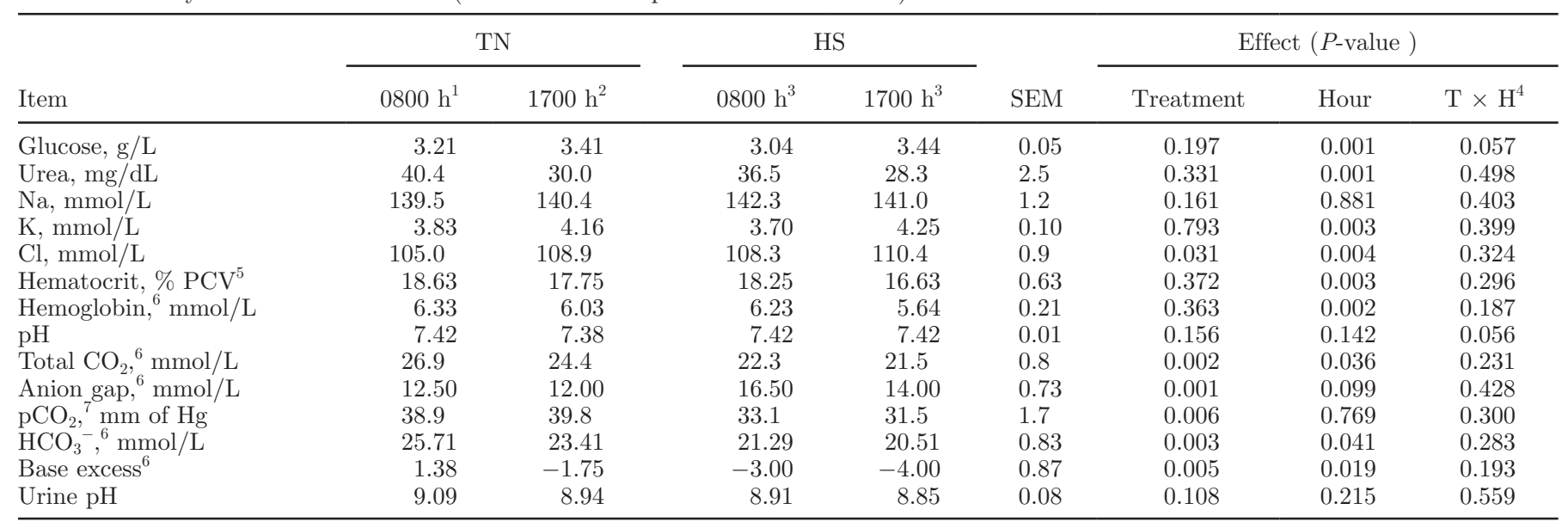

\footnotetext{
${ }^{2}$ During the day $\left(37^{\circ} \mathrm{C}\right.$ and $40 \%$ humidity; THI $\left.=85\right)$ conditions.

${ }^{3}$ Indoor daily variation from 15 (night) to $20^{\circ} \mathrm{C}$ (day) at $45 \%$ relative humidity (THI $=59$ to 65 ).

${ }^{4}$ Treatment $(\mathrm{T}) \times$ hour $(\mathrm{H})$ interaction.

${ }^{5} \mathrm{PCV}=$ packed cell volume.

${ }^{6}$ Calculated values by the i-STAT device software (Abbott Point of Care Inc., Princeton, NJ).

${ }^{7}$ Partial pressure of $\mathrm{CO}_{2}$.
}

${ }^{1}$ Before changing from night $\left(30.5^{\circ} \mathrm{C}\right.$ and $40 \%$ humidity; THI $\left.=77\right)$ to day $\left(37^{\circ} \mathrm{C}\right.$ and $40 \%$ humidity; THI $\left.=85\right)$ conditions

increased serum haptoglobin concentration and hepatic lipidosis in periparturient dairy cows. Hiss et al. (2009) found that elevated haptoglobin concentrations in milk of dairy cows were associated with high NEFA values in early lactation. This relationship was also observed in our HS goats.

It seems that HS goats at $\mathrm{d} 7$ responded by increased circulating haptoglobin when they were metabolically challenged, as evidenced by reduced feed intake (Figure 2) and greater NEFA concentrations (Figure 3). However, when goats were more adapted to heat stress conditions (i.e., d 28), haptoglobin levels returned to values similar to $\mathrm{TN}$ goats.

\section{Corticosterone in Feces}

Fecal corticosterone has been used to evaluate stress in cows (Morrow et al., 2002). This approach is based on the fact that glucocorticoids are secreted by the adrenal gland after the activation of the hypothalamicpituitary-adrenal axis by a stressor. Circulating glucocorticoids are metabolized (conjugated) in the liver and excreted via the urine and feces.

Corticosterone concentrations in feces did not vary between TN and HS goats and averaged $4.28 \pm 0.55$ $\mathrm{ng} / \mathrm{g}$ of DM. Similarly, HS did not increase plasma cortisol concentrations in cows (Ei-Nouty et al., 1978) and goats (Olsson and Dahlborn, 1989). Nevertheless, it should be stressed that fecal samples were collected at $\mathrm{d} 35$, and it is possible that differences between $\mathrm{TN}$ and HS goats would have been detected if fecal corticosterone was measured earlier (i.e., at d 7 when HS goats were suffering greater metabolic stress).

\section{CONCLUSIONS}

Despite the reduction observed in feed intake of HS goats, they produced similar milk yield to goats under TN conditions in late lactation. However, milk protein content decreased in the HS goats, with no change in milk fat content. Heat-stressed goats had similar $\mathrm{N}$ retention to goats under $\mathrm{TN}$ conditions, indicating that the ingested $\mathrm{N}$ might have been directed to other

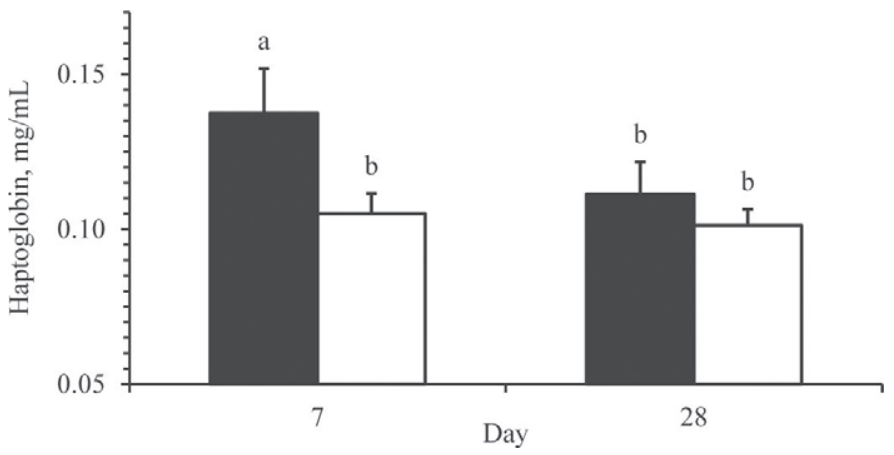

Figure 4. Haptoglobin concentrations in plasma of dairy goats under thermal neutral (TN; $\square ; \mathrm{n}=8$ ) or heat stress (HS; $\mathbf{\square}$ n $=8$ ) conditions at late lactation. Values are means, with SE indicated by vertical bars. Means with different letters ( $\mathrm{a}$ and $\mathrm{b})$ differ $(P<0.05)$. 
metabolic functions rather than milk protein synthesis. Further studies are needed to test the HS effects during early lactation and to clarify whether reduced milk protein content is related to a nutrient-limiting factor or reduced mammary protein synthesis, as well as to evaluate the effects on the coagulation properties of the milk.

\section{ACKNOWLEDGMENTS}

This work is part of a research project funded by the Spanish Ministry of Economy and Finance (Madrid; Plan Nacional I+D+i; Project AGL2009-09376) and was also supported by a research scholarship to S. Hamzaoui from the International Centre for Advanced Mediterranean Agronomic Studies (Instituto Agronómico Mediterráneo de Zaragoza, Zaragoza, Spain). The authors are also grateful to the team of Servei de Granges i Camps Experimentals (SGCE) of the Universitat Autònoma de Barcelona for the care of the animals.

\section{REFERENCES}

Abdalla, E. B., E. A. Kotby, and H. D. Johnson. 1993. Physiological responses to heat-induced hyperthermia of pregnant and lactating ewes. Small Rumin. Res. 11:125-134.

Ametaj, B. N., B. J. Bradford, G. Bobe, R. A. Nafikov, Y. Lu, J. W. Young, and D. C. Beitz. 2005. Strong relationships between mediators of the acute phase response and fatty liver in dairy cows. Can. J. Anim. Sci. 85:165-175.

AOAC International. 2003. Official Methods of Analysis of AOAC International. Vol. I. 17th ed. AOAC International, Gaithersburg, MD.

Baker, M. A. 1989. Effects of dehydration and rehydration on thermoregulatory sweating in goats. J. Physiol. 417:421-435.

Baumgard, L. H., and R. P. Rhoads Jr. 2013. Effects of heat stress on postabsorptive metabolism and energetics. Annu. Rev. Anim. Biosci. 1:311-337.

Bernabucci, U., P. Bani, B. Ronchi, N. Lacetera, and A. Nardone. 1999. Influence of short- and long-term exposure to a hot environment on rumen passage rate and diet digestibility by Friesian heifers. J. Dairy Sci. 82:967-973.

Bernabucci, U., N. Lacetera, and B. Ronchi. 2002. Effects of the hot season on milk protein fractions in Holstein cows. Anim. Res. $51: 25-33$.

Brown, D. L., S. R. Morrison, and G. E. Bradford. 1988. Effects of ambient temperature on milk production of Nubian and Alpine goats. J. Dairy Sci. 71:2486-2490.

Calamari, L., F. Abeni, F. Calegari, and L. Stefanini. 2007. Metabolic conditions of lactating Friesian dairy cows during the hot season in the Po valley. 2. Blood minerals and acid-base chemistry. Int. J. Biometeorol. 52:97-107.

Collier, R. J., C. M. Stiening, B. C. Pollard, M. J. VanBaale, L. H. Baumgard, P. C. Gentry, and P. M. Coussens. 2006. Use of gene expression microarrays for evaluating environmental stress tolerance at the cellular level in cattle. J. Anim. Sci. 84(E. Suppl.):E1-E13.

Constable, P. D. 1999. Clinical assessment of acid-base status: Strong ion difference theory. Vet. Clin. North Am. Food Anim. Pract. 15:447-471.

Ei-Nouty, F. D., I. M. Elbanna, and H. D. Johnson. 1978. Effect of adrenocorticotropic hormone on plasma glucocorticoids and an- tidiuretic hormone of cattle exposed to 20 and $33^{\circ} \mathrm{C}$. J. Dairy Sci. 61:189-196.

Hirayama, T., K. Katoh, and Y. Obara. 2004. Effects of heat exposure on nutrient digestibility, rumen contraction and hormone secretion of goats. Anim. Sci. J. 75:237-243.

Hiss, S., C. Weinkauf, S. Hachenberg, and H. Sauerwein. 2009. Relationship between metabolic status and the milk concentrations of haptoglobin and lactoferrin in dairy cows during early lactation. J. Dairy Sci. 92:4439-4443.

Huber, J. T., G. Higginbotham, R. A. Gomez-Alarcon, R. B. Taylor, K. H. Chen, S. C. Chan, and Z. Wu. 1994. Heat stress, interactions with protein, supplemental fat and fungal cultures. J. Dairy Sci. 77:2080-2090.

INRA (Institut National de la Recherche Agronomique). 2007. Alimentation des bovins, ovins et caprins. Quae, Paris, France.

Joshi, B. C., R. E. McDowell, and D. P. Sadhu. 1968. Effect of drugs on sweating rates in Hariana cattle. J. Dairy Sci. 51:905-909.

Kadzere, C. T., M. R. Murphy, N. Silanikove, and E. Maltz. 2002. Heat stress in lactating dairy cows: A review. Livest. Prod. Sci. 77:59-91.

Lough, D. S., D. K. Beede, and C. J. Wilcox. 1990. Effects of feed intake and thermal stress on mammary blood flow and other physiological measurements in lactating dairy cows. J. Dairy Sci. 73:325-332.

Maloiy, M. O., and C. R. Taylor. 1971. Water requirements of African goats and haired-sheep. J. Agric. Sci. 77:203-208.

Masero, E. J., and P. D. Siegel. 1977. Acid-Base Regulation: Its Physiology and Pathophysiology and the Interpretation of Blood-Gas Analysis. 2nd ed. W. B. Saunders, Philadelphia, PA.

McDowell, R. E., E. G. Moody, P. J. Van Soest, R. P. Lehmann, and G. L. Ford. 1969. Effect of heat stress on energy and water utilization of lactating cows. J. Dairy Sci. 52:188-194.

Mitra, R. G., G. I. Christison, and H. D. Johnson. 1972. Effect of prolonged thermal exposure on growth hormone $(\mathrm{GH})$ secretion in cattle. J. Anim. Sci. 34:776-779.

Morrow, C. J., E. S. Kolver, G. A. Verkerk, and L. R. Mathews. 2002. Fecal glucocorticoid metabolites as a measure of adrenal activity in dairy cattle. Gen. Comp. Endocrinol. 126:229-241.

NRC. 1971. A Guide to Environmental Research on Animals. National Academies Press, Washington, DC.

NRC. 2007. Nutrient Requirements of Small Ruminants, Sheep, Goats, Cervids, and New World Camelids. National Academies Press, Washington, DC.

Olsson, K., and K. Dahlborn. 1989. Fluid balance during heat stress in lactating goats. Q. J. Exp. Physiol. 74:645-659.

Olsson, K., M. Josäter-Hermelin, J. Hossaini-Hilali, E. Hydbring, and K. Dahlborn. 1995. Heat stress causes excessive drinking in fed and food deprived pregnant goats. Camp. Biochem. Physiol. 110:309-317.

Pugh, D. G., and N. Baird. 2012. Sheep and Goat Medicine. Elsevier Saunders, Maryland Heights, MO.

Rhoads, M. L., R. P. Rhoads, M. J. VanBaale, R. J. Collier, S. R. Sanders, W. J. Weber, B. A. Crooker, and L. H. Baumgard. 2009. Effects of heat stress and plane of nutrition on lactating Holstein cows: I. Production, metabolism, and aspects of circulating somatotropin. J. Dairy Sci. 92:1986-1997.

Sano, H., K. Ambo, and T. Tsuda. 1985. Blood glucose kinetics in whole body and mammary gland of lactating goats exposed to heat stress. J. Dairy Sci. 68:2557-2564.

Schneider, P. L., D. K. Beede, and C. J. Wilcox. 1988. Nycterohemeral patterns of acid-base status, mineral concentrations and digestive function of lactating cows in natural or chamber heat stress environments. J. Anim. Sci. 66:112-125.

Shwartz, G., M. L. Rhoads, M. J. VanBaale, R. P. Rhoads, and L. H. Baumgard. 2009. Effects of a supplemental yeast culture on heatstressed lactating Holstein cows. J. Dairy Sci. 92:935-942.

Silanikove, N. 2000. The physiological basis of adaptation in goats to harsh environments. Small Rumin. Res. 35:181-193.

West, J. W. 2003. Effects of heat-stress on production in dairy cattle. J. Dairy Sci. 86:2131-2144. 